\section{EREM 74/1}

Journal of Environmental Research, Engineering and Management

Vol. 74 / No. 1 / 2018

pp. $35-42$

DOI 10.5755/j01.erem.74.1.19930

(C) Kaunas University of Technology

\section{Application of Industrial by Products in High Strength Glass Fiber Reinforced Concrete}

Received 2018/02
Accepted after revision 2018/03

\title{
Application of Industrial by Products in High Strength Glass Fiber Reinforced Concrete
}

\section{Virendra Kumara K N}

Associate Professor, Department of Civil Engineering, VVIT, Bengaluru

\section{S B Anadinni}

Principal, VVIT, Bengaluru

Corresponding author: virendrakumara80@gmail.com

Associate Professor, Department of Civil Engineering, VVIT, Bengaluru

With the ecological imbalance in the nature due to exploitation of natural sand from rivers, there is much need to utilize the industrial wastes in concrete as a part to replace the natural sand deficiency and also as to develop sustainable environment in construction industry. High strength and durability properties being the key components of High performance concrete can be produced by using some admixtures like fly ash and silica fume. In the present study, fly ash and silica fume are taken as steady replacement of 15\% and 10\% respectively for cement. Bottom ash is introduced in place of sand at the variations of $0 \%, 10 \%, 20 \%, 30 \%, 40 \%$ and $50 \%$. Glass fibers of $0.2 \%$ are added as extra ingredient as to improve some properties. The properties of strength, drying shrinkage and water absorption are studied for the M60 grade HSGFRC (High Strength Glass Fiber Reinforced Concrete) designation. The results showed that the concrete with $40 \%$ bottom ash had the optimum strength.

Keywords: Bottom ash, drying shrinkage, fly ash, silica fume, strength.

\section{Introduction}

Concrete being an easily prepared material by using naturally available raw material has become abundantly used construction material in the world than any other material except water. For the present construction world, concrete with high strength aspects made with sustainable resources is a challenge in the civil industry. In regard to this, concrete with industrial wastes that have pozzolonic properties can 
be utilized in production of high strength concrete. Mean while the waste products of industries will get utilized in concrete, reducing environmental pollution impact and reducing exploitation of natural raw materials. Fly ash and bottom ash, the waste products of coal combustion units are produced in the world of about more than 110 million tons of which only $30 \%$ $40 \%$ of ashes are utilized at various fields. Silica fume, a tiny particle sized waste produced in the electric arc furnace in the production of silica have pozzolonic properties and give good strength to concrete.

For the present study, fly ash and silica fume are utilized in the steady fractions of $15 \%$ and $10 \%$ respectively as replacement to cement. Bottom ash is introduced as replacement to natural sand at a percentage variation of $10 \%, 20 \%, 30 \%, 40 \%$ and $50 \%$. Glass fibers produced as wastes in the glass manufacturing industries are used at a constant $0.2 \%$ by volume of concrete as an extra ingredient to improve some properties to concrete.

The concrete is designed for M60 grade and the strength properties of concrete like compressive strength, split tensile strength and flexural strength are studied. The durability properties like drying shrinkage of concrete and water absorption are tested for the concrete produced and compared with the controlled concrete.

\section{Related work}

Concrete with high strength requires a wide range of materials for its production. The materials in combination and in separate possess separate percentage level replacements to achieve good strength in concrete. Fly ash and silica fume as separate constituents in concrete can be used upto $30 \%$ and $10 \%$ respectively [3][4]. When these both are adopted in combination, the optimum replacement level is $15 \%$ and $10 \%$ respectively at which optimum strength in concrete can be achieved [2]. Bottom ash as replacement to fine aggregates in concrete can be made upto $30 \%$ as optimum [1][6]. Glass fibers addition to concrete can improve strength properties of concrete [1][5][6][8] and also restricts shrinkage in concrete[1]. The percentage addition of glass fibers can be made from $0.03 \%$ of volume of concrete [5] to $1 \%$ by volume of concrete [6][8]. The investigations made showed that the workability of concrete reduces with the increase in bottom ash content [1][7][9] and also due to glass fibers in the concrete[5]. The strength of concrete with bottom ash reduces at initial stage but it gives good results at the later ages of concrete [1][6][7][9]. The combination of Bottom ash and Glass fibers showed a better flexural strength in concrete [5][6]. For the present investigative study, the concrete is prepared with fly ash and silica fume as constant replacements to cement at $15 \%$ and $10 \%$ respectively. The glass fibers are added at constant $0.2 \%$ and the bottom ash is varied at $0 \%$, $10 \%, 20 \%, 30 \%, 40 \%$ and $50 \%$ replacements to fine aggregates.

\section{Aim}

Many researchers so far have worked on utilization of single pozzolonic material as replacement to cement along with bottom ash but there is no work done on utilization of more than one pozzolonic material as a replacement to cement to produce a hybrid concrete along with bottom ash and glass fibers. This work aims on production of high strength hybrid concrete, study the workability, strength properties, and durability properties. There by aiming to conserve natural resources utilizing industrial waste and produce sustainable hybrid concrete.

\section{Materials}

Cement: Ordinary Portland cement of 53 grade having specific gravity 3.14 , fineness modulus $3.6 \%$ with initial and final setting time 43 minutes and 195 minutes confirming to IS 12269-1987 was used for the investigation.

Fly ash: Class F fly ash confirming to ASTM C618 having specific gravity of 2.2 and fineness modulus 2.5 was utilized. The fly ash supplied from Raichuru Thermal Power Plant was used. 
Silica fume: This was supplied from the local dealer. The silica fume had specific gravity 2.3 , fineness modulus 2.1\%.

Bottom ash: Bottom ash having specific gravity 2.65 and bulk density(compacted)-1420 kg/m ${ }^{3}$ brought from Raichuru Thermal Power Plant was used for the study.

Fine aggregate: Natural river sand with specific gravity 2.65 , bulk density(compacted)- $1624 \mathrm{~kg} / \mathrm{m}^{3}$ free from silt and clay was used for the investigation.

\section{Table 1}

Mix proportion ratio

\begin{tabular}{l|c}
\hline \multicolumn{2}{c}{ M60 Grade conventional Concrete mix Proportion } \\
\hline \multicolumn{1}{c}{1} & 2 \\
\hline Cement & $405.41 \mathrm{~kg} / \mathrm{m}^{3}$ \\
\hline Fly ash & $82.07 \mathrm{~kg} / \mathrm{m}^{3}$ \\
\hline Silica fume & $54.71 \mathrm{~kg} / \mathrm{m}^{3}$ \\
\hline Fine aggregate & $585.23 \mathrm{~kg} / \mathrm{m}^{3}$ \\
\hline Coarse aggregate & $1135.5 \mathrm{~kg} / \mathrm{m}^{3}$ \\
\hline Water & $174.15 \mathrm{~kg} / \mathrm{m}^{3}$ \\
\hline
\end{tabular}

Mix Ratio $=\mathrm{C}: \mathrm{FA}: \mathrm{CA}: \mathrm{w} / \mathrm{C}$

Mix Ratio $=1: 1.10: 2.093: 0.3$ (0.8\% superplasticizer)

Coarse aggregate: Crushed stones of angular shaped aggregates of specific gravity 2.68 , bulk density (compacted) $-1599 \mathrm{~kg} / \mathrm{m}^{3}$ which are clean, hard, durable free from clay, organic and vegetable matters, fine dust are utilized for the study.

Glass fibers: Cem fil Anti-crack HP glass fibers of diameter 14 microns and length $12 \mathrm{~mm}$ fibers with aspect ratio of 858 with very high chemical resistant characteristics were used.

Superplasticizer: Glenium 8233 of M/s BASF Construction Chemicals Pvt Ltd. confirming to IS 91031999 is used

Water: Portable drinking water was used for the project.

Mix design: Mix design was done as per IS 10262 2009, concrete mix was prepared for M60 grade. The mix proportion is shown in table.

\section{Methods, Results and Discussion}

Workability test: Slump test was conducted to find the workability of concrete. It was done as per IS 1199-1959 code specifications. Standard slump cone and tamping rod were used for slump test. Slump of $90 \mathrm{~mm}$ to $110 \mathrm{~mm}$ was chosen for workability. The concrete resulted that the bottom ash contained concrete needs extra superplasticizer to maintain the slump within range. The slump went on decreasing with increase in bottom ash percentage. For this purpose, the superplasticizer had to be adjusted to get the slump in the workability range of $90 \mathrm{~mm}$ to $110 \mathrm{~mm}$.

\section{Strength Tests:}

Compressive strength test: Compressive test was conducted on standard cubes of size $150 \mathrm{~mm} \times 150 \mathrm{~mm}$ $x 150 \mathrm{~mm}$. Compression testing machine confirming to IS 516-1956 was used. The strength was found for 28,56 and 90 days cured specimens. The maximum load at which the specimen breaks is noted and compared with conventional concrete.

\section{Compressive strength, $f_{c}=P / A$}

Where, $f_{c}$ - ompressive strength of cube in $\mathrm{N} / \mathrm{mm}^{2}$, $P$ - compressive load causing failure in $\mathrm{N} / \mathrm{mm}^{2}$, A - Cross sectional area of cube in $\mathrm{mm}^{2}$

\section{Table 2}

Compression strength test result values of M60 HSGFRC

\begin{tabular}{c|c|c|c|c}
\hline $\begin{array}{c}\text { Sl. } \\
\text { No. }\end{array}$ & $\begin{array}{c}\% \\
\text { replacement } \\
\text { of bottom } \\
\text { ash }\end{array}$ & $\begin{array}{c}28 \text { days } \\
\text { compressive } \\
\text { strength(N/ } \\
\left.\mathrm{mm}^{2}\right)\end{array}$ & $\begin{array}{c}56 \text { days } \\
\text { compressive } \\
\text { strength(N/ } \\
\left.\mathrm{mm}^{2}\right)\end{array}$ & $\begin{array}{c}90 \text { days } \\
\text { compressive } \\
\text { strength(N/ } \\
\left.\mathrm{mm}^{2}\right)\end{array}$ \\
\hline 1 & 2 & 3 & 4 & 5 \\
\hline 1 & CC & 63.11 & 68.14 & 68.88 \\
\hline 2 & $0 \%$ BA & 64.14 & 69.63 & 69.92 \\
\hline 3 & $10 \%$ BA & 60.29 & 69.78 & 70.07 \\
\hline 4 & $20 \%$ BA & 59.11 & 69.92 & 70.66 \\
\hline 5 & $30 \%$ BA & 58.51 & 70.81 & 71.40 \\
\hline 6 & $40 \%$ BA & 56.44 & 71.11 & 72.29 \\
\hline 7 & $50 \%$ BA & 55.40 & 70.22 & 70.51 \\
\hline
\end{tabular}


Fig. 1

Compressive Strength versus \% variation of bottom ash of M60 HSGFRC for different days of curing

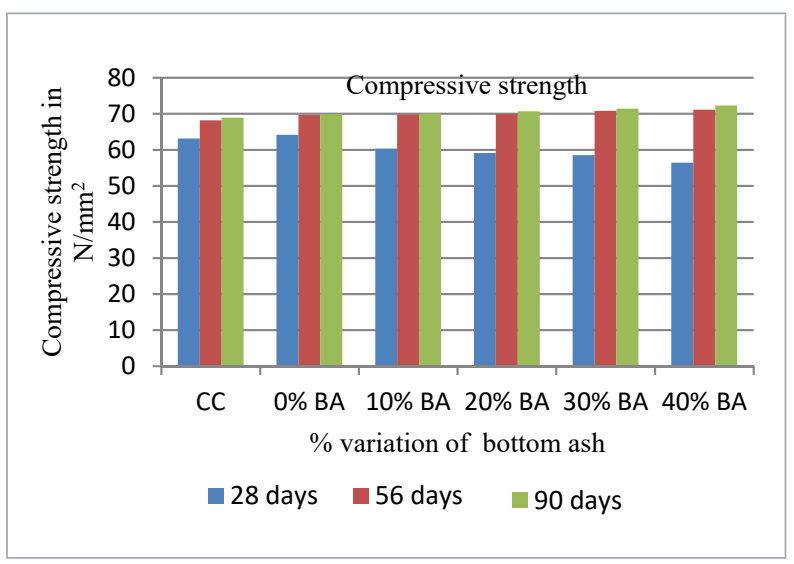

The result showed that at the 28 days, the strength of concrete without bottom ash showed a good strength, but the concrete with bottom ash showed a decrease in strength. This shows that the concrete with fly ash and bottom ash are of slow hydrating but the silica fume showed a positive response at the early age. At the later ages of 56 and 90 days, the concrete strength was increased with bottom ash increment which was due to later hydration of fly ash and bottom ash. The increase in strength was also due to increase in finer particles in bottom ash. Bottom ash being an active particle in concrete gave pozzolonic action with lime content of cement along with fly ash and silica fume. But this increment was only upto $40 \%$ replacement of bottom ash. An optimum of $72.29 \mathrm{~N} / \mathrm{mm}^{2}$, i.e., $4.95 \%$ higher strength was noted at the 90 days which was maximum.

Split tensile strength: The test specimens of $300 \mathrm{~mm}$ length and $150 \mathrm{~mm}$ diameter cylinders were casted for finding split tensile strength of concrete. Compression testing machine was used for testing. The cylindrical specimens of 28, 56 and 90 days cured ones were subjected to indirect loading. Split failure load is noted and the split tensile strength is calculated using the formula.

The results showed that the tensile strength decreased at 28 days with increase in bottom ash and then at 56 and 90 days, the strengths went on increasing with bottom ash upto $40 \%$ replacement of bottom ash. But for concretes of all variations of bottom ash

\section{Table 3}

Split Tensile strength test result values of M60 HSGFRC

\begin{tabular}{c|c|c|c|c}
\hline $\begin{array}{c}\text { Sl. } \\
\text { No. }\end{array}$ & $\begin{array}{c}\% \\
\text { replacement } \\
\text { of bottom } \\
\text { ash }\end{array}$ & $\begin{array}{c}28 \text { days } \\
\text { Split tensile } \\
\text { strength(N/ } \\
\left.\mathrm{mm}^{2}\right)\end{array}$ & $\begin{array}{c}56 \text { days } \\
\text { split tensile } \\
\text { strength(N/ } \\
\left.\mathrm{mm}^{2}\right)\end{array}$ & $\begin{array}{c}90 \text { days } \\
\text { split tensile } \\
\text { strength(N/ } \\
\left.\mathrm{mm}^{2}\right)\end{array}$ \\
\hline 1 & 2 & 3 & 4 & 5 \\
\hline 1 & CC & 6.27 & 6.83 & 6.88 \\
\hline 2 & $0 \% \mathrm{BA}$ & 6.43 & 6.97 & 7.00 \\
\hline 3 & $10 \% \mathrm{BA}$ & 6.06 & 6.97 & 7.02 \\
\hline 5 & $20 \% \mathrm{BA}$ & 5.89 & 7.00 & 7.07 \\
\hline 6 & $40 \% \mathrm{BA}$ & 5.68 & 7.12 & 7.19 \\
\hline 7 & $50 \% \mathrm{BA}$ & 5.61 & 7.05 & 7.05 \\
\hline
\end{tabular}

Fig. 2

Split tensile Strength versus \% variation of bottom ash of M60 HSGFRC for different days of curing

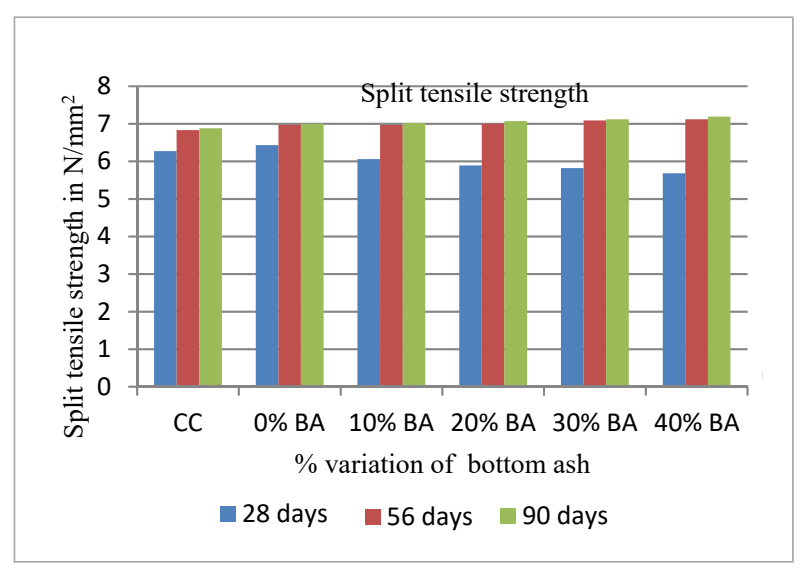

the strength was above the strength of conventional concrete. This increase in strength is due to good bonding within the particles and also due to glass fibers inter linking.

Flexural strength: Beams of size $150 \mathrm{~mm} \times 150 \mathrm{~mm} \times$ $700 \mathrm{~mm}$ was used and tested under two point loading under standard universal testing machine. The values of failure were noted and flexural strength was calculated.

The beams produced to two point loading resulted that there was a decline in flextural strength at the initial 


\section{Table 4}

Flexural strength test result values of M60 HSGFRC

\begin{tabular}{c|c|c|c|c}
\hline $\begin{array}{r}\text { Sl. } \\
\text { No. }\end{array}$ & $\begin{array}{c}\text { \% replacement of } \\
\text { bottom ash }\end{array}$ & $\begin{array}{c}28 \text { days } \\
\text { flexural } \\
\text { strength } \\
\left(\mathrm{N} / \mathrm{mm}^{2}\right)\end{array}$ & $\begin{array}{c}56 \text { days } \\
\text { flexural } \\
\text { strength } \\
\left(\mathrm{N} / \mathrm{mm}^{2}\right)\end{array}$ & $\begin{array}{c}90 \text { days } \\
\text { flexural } \\
\text { strength } \\
\left(\mathrm{N} / \mathrm{mm}^{2}\right)\end{array}$ \\
\hline 1 & 2 & 3 & 4 & 5 \\
\hline 1 & CC & 5.57 & 5.76 & 5.81 \\
\hline 2 & $0 \%$ BA & 5.59 & 5.84 & 5.85 \\
\hline 3 & $10 \%$ BA & 5.42 & 5.85 & 5.86 \\
\hline 4 & $20 \%$ BA & 5.37 & 5.86 & 5.89 \\
\hline 5 & $30 \%$ BA & 5.35 & 5.91 & 5.91 \\
\hline 6 & $40 \%$ BA & 5.29 & 5.92 & 5.95 \\
\hline 7 & $50 \%$ BA & 5.19 & 5.87 & 5.87 \\
\hline & & & & \\
\hline
\end{tabular}

\section{Fig. 3}

Flexure Strength versus \% variation of bottom ash of M60 HSGFRC for different days of curing

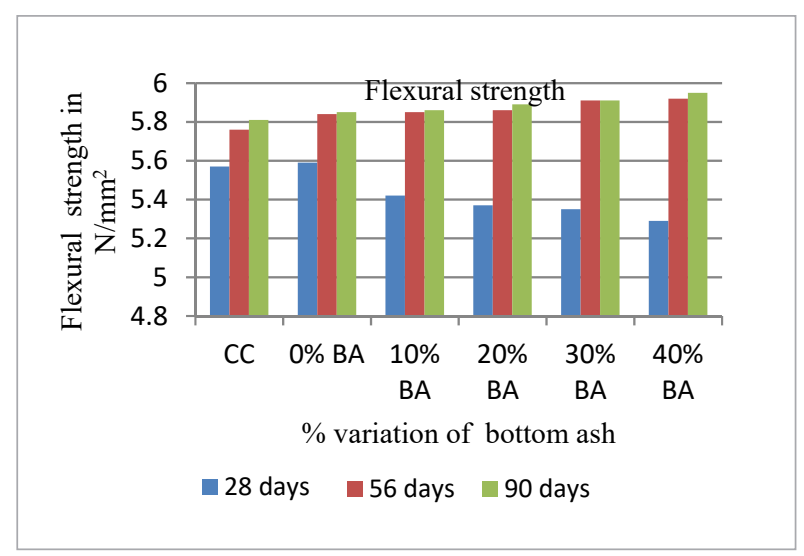

stages. Then at the later stages of 56 and 90 days, the strength increased with the gain in strength/bond in the concrete and also due to the interlocking of fibers in concrete. The maximum value was obtained for concrete with $40 \%$ replacement of natural sand by bottom ash.

Drying shrinkage: The drying shrinkage test was conducted on the specimens of size $100 \mathrm{~mm} \times 100 \mathrm{~mm}$ $\times 300 \mathrm{~mm}$. The concrete specimens are casted with rounded end screw fittings of diameter $6.5 \mathrm{~mm}$ and moist cured for a period of 7 days. Then the specimen was cured in water for 28,56 and 90 days. A length comparator was used for checking lengths with a dial gauge fixed to read the readings which is of accuracy $0.002 \mathrm{~mm}$. The cured specimens are taken out of water and measured for original wet measurement. Then the specimens were oven dried regulating a temperature of $50 \pm 5^{\circ} \mathrm{C}$ for atleast 44 hours. Then they were removed off the oven and cooled in a descicator for 4 hours and checked for dry measurement. This oven drying, cooling and measuring is repeated until the measurements comes to constant. This measurement is noted as final dry measurement. The percentage of dry shrinkage was calculated by finding the difference between original wet and dry measurements to the dry length of specimen.

The change in volume due to drying was noted at all days. The drying shrinkage tests showed that the

\section{Table 5}

Drying shrinkage test values of M60 HSGFRC

\begin{tabular}{c|c|c|c|c}
\hline \multirow{2}{*}{$\begin{array}{c}\text { Sl. } \\
\text { No. }\end{array}$} & \% replacement & \multicolumn{3}{|c}{ Shrinkage of concrete } \\
\cline { 3 - 5 } & of bottom ash & 28 days & 56 days & 90 days \\
\hline 1 & 2 & 3 & 4 & 5 \\
\hline 1 & CC & 0.0020 & 0.0019 & 0.0018 \\
\hline 2 & $0 \%$ BA & 0.0012 & 0.0012 & 0.0011 \\
\hline 3 & $10 \%$ BA & 0.0015 & 0.0014 & 0.0013 \\
\hline 4 & $20 \%$ BA & 0.0014 & 0.0013 & 0.0012 \\
\hline 5 & $30 \%$ BA & 0.0013 & 0.0012 & 0.0012 \\
\hline 6 & $40 \%$ BA & 0.0013 & 0.0012 & 0.0011 \\
\hline 7 & $50 \%$ BA & 0.0013 & 0.0012 & 0.0011 \\
\hline
\end{tabular}

Fig. 4

Drying Shrinkage versus \% variation of bottom ash of M60 HSGFRC for different days of curing

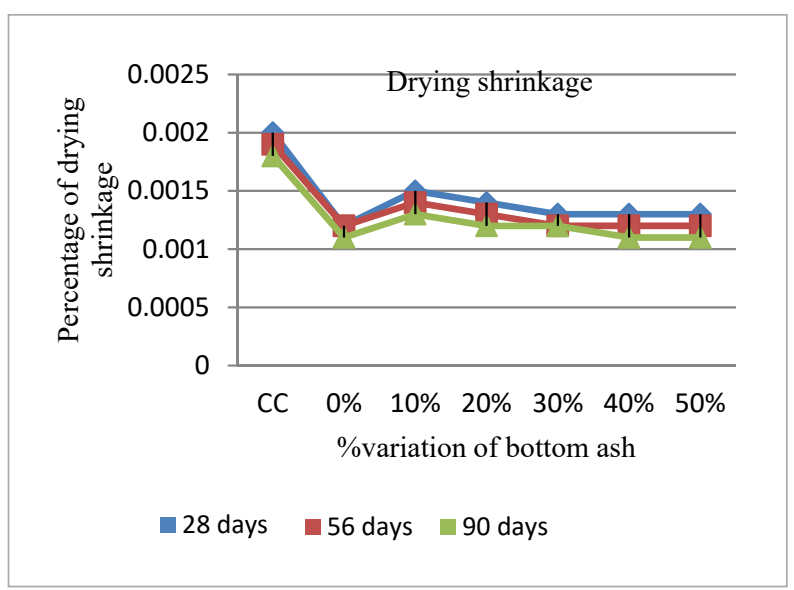


conventional concrete shrinks greater than the concretes with fibers and bottom ash. The shrinkage decreased with increase in bottom ash content in concrete and also with increase in duration of curing. The reduce in shrinkage is due to fibers arresting the shrinkage of concrete and also the increase in fineness due to increase in bottom ash reduces the shrinkage of concrete.

Water absorption test: The cube specimens of dimension $150 \mathrm{~mm} \times 150 \mathrm{~mm} \times 150 \mathrm{~mm}$ were casted, cured for 28, 56 and 90 days. The specimens after curing were taken out of water and dried in oven at a temperature of $105^{\circ} \mathrm{C}$ for 24 hours. Then the dried specimens are weighed and weight is noted. The weighed specimens were dipped in water for next 24 hours for water absorption. After 24 hours the weight of specimen is noted and the percentage of water absorbed is calculated.

$$
W A=\left(\left(W_{1}-W_{2}\right) / W_{1}\right) \times 100
$$

Where, $W_{1}$ - weight of oven dried specimens; $W_{2}-$ weight of fully saturated specimen.

The water absorption analysis showed that there was an increase in water absorption of concrete with increase in bottom ash increment compared to conventional concrete. This repeated for all ages of concrete. This increment in water absorption was due to the increase in porous bottom ash content in concrete. Higher the bottom ash content higher was the porous nature.

\section{Table 6}

Water absorption values for M60 grade HSGFRC

\begin{tabular}{c|c|c|c|c}
\hline \multirow{2}{*}{$\begin{array}{c}\text { Sl. } \\
\text { No. }\end{array}$} & $\begin{array}{c}\text { \% replacement of } \\
\text { bottom ash }\end{array}$ & \multicolumn{3}{|c}{$\%$ of water absorption } \\
\cline { 4 - 5 } & 28 days & 56 days & 90 days \\
\hline 1 & 2 & 3 & 4 & 5 \\
\hline 1 & CC & 1.153 & 1.092 & 0.915 \\
\hline 2 & $0 \%$ BA & 1.328 & 1.21 & 1.025 \\
\hline 3 & $10 \%$ BA & 1.332 & 1.416 & 1.189 \\
\hline 4 & $20 \%$ BA & 1.366 & 1.555 & 1.366 \\
\hline 5 & $30 \%$ BA & 1.397 & 1.682 & 1.581 \\
\hline 6 & $40 \%$ BA & 1.666 & 1.922 & 1.823 \\
\hline 7 & $50 \%$ BA & 1.895 & 2.064 & 1.92 \\
\hline
\end{tabular}

Fig. 5

Water absorption versus \% variation of bottom ash of M60 HSGFRC for different days of curin

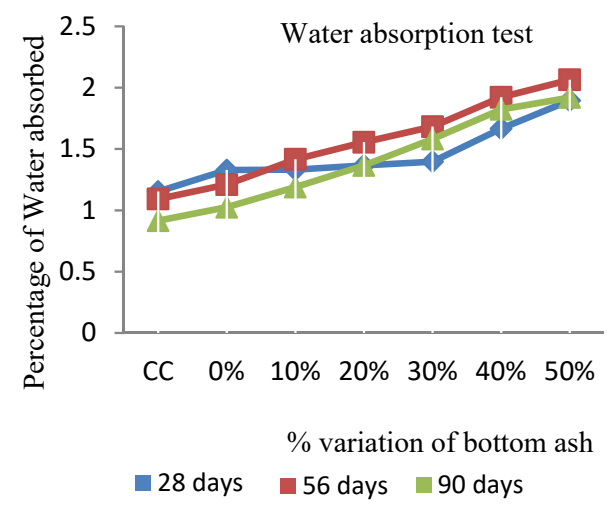

\section{Conclusion}

High strength concrete can be produced using constant variation of fly ash and bottom ash with variable variation of bottom ash along with glass fibers and superplasticizers.

Workability of concrete with bottom ash and fibers reduces with increases in bottom ash increment which is due to the more absorption capacity of bottom ash.

The compressive strength at 28 days decreases with increase in bottom ash content which is due to the lower hydration of fly ash at lower ages but the good strength in $0 \%$ bottom ash concrete was due to the impact of silica fume.

The compressive strength increases at 56 and 90 days upto $40 \%$ replacement level of bottom ash which is maximum replacement level but overall upto 50\% replacement of bottom ash can be made with constant levels of fly ash and silica fume. A 4.95\% higher strength than normal concrete was noted at 90 days in $40 \%$ bottom ash concrete.

The split tensile strength at 28 days reduced but at 56 and 90 days, the split tensile strength increased with increase in bottom ash content upto $40 \%$ replacement of bottom ash. The glass fibers and increase in the finer particles in concrete improved tensile strength.

The flexural strength increased with increase in bottom ash replacement levels. The optimum value was obtained for $40 \%$ replacement level but upto $50 \%$ re- 
placement can be made since the value at $50 \%$ was well above the value of conventional concrete.

The drying shrinkage value at all the three days for conventional concrete was more than concrete with fly ash, silica fume, and bottom ash and glass fibers. The introduction of glass fibers had arrested the shrinkage of concrete. And also the shrinkage decreased with increase in curing period since the drying period is ever lasting process.

Water absorption test showed an increase in water absorption capacity of concrete with increase in bottom ash at all the ages which is due to more water absorption of bottom ash.

\section{References}

Arun kumar A, A.S. Santhi and G.Mohan Ganesh, "Strength and Drying Shrinkage of Green Concrete" Indian Concrete Journal, Vol. 88, Feb 2014

H S Jadhav and R R Chavarekar "Role of Fly Ash and Silica Fume on Compressive Strength Characteristics of High Performance Concrete", IJSCER Vol. 2, No. 1, Feb 2013

Girish.S, Karisiddappa and Amar.R "Experimental Study to Obtain Optimum Replacement Percentage of Flyash and Addition of Silica Fume in Blended Concrete", International Journal of Research (IJR) Vol.-1, Issue-7, Aug 2014

Dilip Kumar Singha Roy and Amitava Sil, "Effect of Partial Replacement of Cement by Silica Fume on Hardened Concrete", International Journal of Emerging Technology and Advanced Engineering, Vol. 2, Issue 8, August 2012

Avinash Gornale, S Ibrahim Quadri, S Mehmood Quadri, Syed Md Akram Ali and Syed Shamsuddin Hussaini., "Strength As- pects of Glass Fiber Reinforced Concrete", International Journal of Scientific \& Engineering Research, Vol. 3, Issue 7, July-2012

P. Bhuvaneshwari and R. Murali, "Strength Characteristics of Glass Fiber on Bottom Ash Based Concrete", International Journal of Science, Environment and Technology, Vol. 2, No 1, pp. 90102, 2013.

P. Aggarwal, Y. Aggarwal and S.M. Gupta, "Effect of Bottom Ash as Replacement of Fine Aggregates in Concrete", Asian Journal of Civil Engineering (Building And Housing) Vol. 8, No. 1 (2007).

Deshmukh S.H., Bursary J. P and Zoned A. M. "Effect of Glass Fibers on Ordinary Portland cement Concrete", IOSR Journal of Engineering, June. 2012, Vol. 2(6) pp. 1308-1312.

Abdulhameed Umar Abubakar and Khairul Salleh Baharudin, "Properties of Concrete Using TANJUNG BIN Power Plant Coal Bottom Ash and Fly Ash", International Journal of Sustainable Construction Engineering \& Technology (ISSN: 2180-3242), Vol. 3, Issue 2, 2012

\section{Pramonès šalutinių produktų įterpimas į didelio atsparumo stiklo pluoštu sustiprintą betoną}

\section{Virendra Kumara K N, S B Anadinni}

Civilinės inžinerijos katedra, VVIT, Bengaluru

Atsižvelgiant i gamtos ekosistemos pusiausvyrą dèl natūralaus smèlio iš upių eksploatacijos, pramoninèms atliekoms betono gamyboje yra daug, kad būtu galima pakeisti natūralu smèlio trūkumą, taip pat kuriant tvarią aplinką statybos pramonèje. Didelio stiprumo ir ilgaamžiškumo savybès, kurios yra pagrindiniai komponentai iš aukšto efektyvumo betono, gali būti pagaminti naudojant tam tikrus priedus, tokius kaip lakieji pelenai ir silicio dioksido dūmai. Šiame tyrime lakieji pelenai ir silicio dioksido dūmai yra laikomi stabiliu 15\% ir 10\% pakeitimu cemento atžvilgiu. Grunto pelenai jvedami vietoje smèlio esant 0\%, 10\%, 20\%, 30\%, 40\% ir 50\% svyravimams. Stiklo pluoštai, kurių kiekis yra 0,2\%, yra papildomas ingredientas, siekiant pagerinti kai kurias savybes. M60 klasès HSGFRC (aukšto stiprumo stiklo pluoštu ar armuotu betonu) pavadinime yra ištirtos stiprumo savybès, džiūvimo susitraukimas ir vandens absorbcija. Rezultatai parode, kad betono su 40\% dugno pelenais buvo optimalus stipris.

Raktiniai žodžiai: lakieji pelenai, silicio dioksido dūmai, betonas, stiklo pluoštas. 